\title{
Evaluation of Microbial Load of Beef of Arsi Cattle in Adama Town, Oromia, Ethiopia
}

\author{
Arse Gebeyehu $^{1 *}$, Mohammed Yousuf ${ }^{2}$ and Ameha Sebsibe ${ }^{3}$
}

${ }^{1}$ Adami Tulu Agricultural Research Center, P.o.box 35, Batu, East Shoa, Ethiopia

${ }^{2}$ Haramaya University, P.o.box 138, Dire Dawa, Ethiopia

${ }^{3}$ Food and Agricultural Organization, Ethiopia, P.o.box 5536, Addis Ababa, Ethiopia

\begin{abstract}
The study was conducted in Adama town, on carcass samples collected from the Arsi breed of cattle with the objective of evaluating beef microbiological qualities with standard procedures. Carcass samples were randomly chosen at abattoir using systematic random sampling techniques. On the night carcass sampling about 125 cattle were slaughtered and the carcass samples were chosen on every 10 counting. Beef samples were aseptically excised and collected from all parts of the exposed body of carcasses. The methods described by the Nordic Committee on Food Analysis (NMKL) were adopted to analyze each of the parameters considered. Aerobic plate count, total coliform count and fecal coliform counts were significantly different among different sampling days and batches of samples $(P<0.05)$. The mean AP, Total coliform, Fecal coliform, E. coli and staphylococci counts were $1.62 \times 10^{5}$, $5.29 \times 10^{1}, 9.05 \times 10^{1}, 8.97 \times 10^{1}$ and $5.54 \times 10^{5}$, respectively. Salmonella and Shigella bacteria were not isolated per $25 \mathrm{~g}$ samples. In Adama, carcasses are normally transported to the butchers' shop either in vans, minibus, taxi, three wheel motor cycle and horse-cart. This exposes the meat to a number of pathogens some of which may be pathogenic. Therefore, since the general hygienic condition of the abattoir and carcass harvesting process was poor, beef consumers in Adama are advised to eat properly cooked beef to avoid intoxication due microbes.
\end{abstract}

Keywords: Aerobic plate count; Total coliform count; Fecal coliform count; E. coli and Staphylococci count

\section{Introduction}

Ethiopia is one of the top possessors of livestock in Africa with an estimated population of 52.13 million, 24.22 million, and 22.62 million heads of cattle, sheep and goats, respectively (CSA, 2012). This livestock is playing an important role in the national economy, contributing to both agricultural products and national GDP [1-3]. But the contribution of livestock and livestock products export to earn foreign exchange is not too large due to the fact that the country is not fully exploiting this resource. Several studies reveal that the production and productivity of the animal is low and products being produced are of low quality [1].

According to MoFED [4] annual report, the national economy is growing in not less than double digits. This economic growth is likely to stimulate people's interest to high quality and value added products [5]. Education and economic prosperity makes people more sensitive and selective to matters they use particularly healthier consumption of foods [6]. In virtue of this, meat commercialization has a great potential to become a key source of income to smallholders of Ethiopia.

As a result, in recent years feedlot firms are flourishing and getting engaged in the export of processed meat to the Middle East and North African (MENA) and absorbing foreign currency from international markets. Standards, such as acceptable microbial load level are being adopted by almost all international markets $[7,8]$. According to the World Bank [9] report, Ethiopian meat production and marketing has been plagued by lack of quality and sanitation, prevalence of disease and unqualified meat production process.

Several scientists have indicated the importance of continuous assessment on meat microbial load qualities. Kirton, Herenda and von-Braun [7,10-11] recommend the continuous investigation and inspection of meat to provide safe and wholesome meat for human consumption. As far as microbial load level of Ethiopian meat is concerned there is limited information on the microbial quality of Ethiopian beef that is being retailed in different outlets. Plus, the need for assuring safety cannot be underestimated in this modern world. Therefore, this study was conducted to assess the sanitary conditions of beef cuts being retailed in various butcheries (from slaughterhouse to butcheries) of Adama town.

\section{Materials and Methods}

\section{Study area}

This study was conducted in Adama town, Ethiopia. Adama town is situated on the high way from Addis Ababa city to Harar. Adama has an altitude of $1666 \mathrm{~m}$ above sea level and located at $100 \mathrm{~km}$ east of Addis Ababa. According to CSA (2012) population census report, Adama town has 271,562 residents. Adama is situated in the center of the country and more frequently visited by national and international tourists. The municipality of Adama town has its own abattoir that gives service to towns' community. The abattoir is semi-modern that operates with services featuring cattle, sheep and goat slaughtering. The annual average minimum and maximum temperatures of Adama town are $18^{\circ} \mathrm{C}$ and $32^{\circ} \mathrm{C}[12,13]$. The specific geographical location of the towns' abattoir is on the geographic coordinates of: $8^{\circ} 33^{\prime} 05.79^{\prime \prime} \mathrm{N}$ and $39^{\circ} 15^{\prime} 34.83^{\prime \prime} \mathrm{E}$. The altitude of the abattoir is 1639 meter above sea level [14].

${ }^{*}$ Corresponding author: Arse Gebeyehu, Adami Tulu Agricultural Research Center, P.o.box 35, Batu, East Shoa, Ethiopia, E-mail: arse.gebeyehu@yahoo.com Received May 08, 2013; Accepted May 02, 2013; Published May 10, 2013

Citation: Gebeyehu A, Yousuf M, Sebsibe A (2013) Evaluation of Microbial Load of Beef of Arsi Cattle in Adama Town, Oromia, Ethiopia. J Food Process Technol 4: 234. doi:10.4172/2157-7110.1000234

Copyright: ( 2013 Gebeyehu A, et al. This is an open-access article distributed under the terms of the Creative Commons Attribution License, which permits unrestricted use, distribution, and reproduction in any medium, provided the original author and source are credited. 


\section{Sample collection and preparations}

A total of 12 carcass samples were collected from 12 cattle slaughtered in the slaughterhouse of Adama town. The carcass samples were collected in two non-consecutive sampling days. The samples were collected by systematic random sampling techniques. In the first day of sampling a total of 63 cattle were slaughtered and the carcass samples were taken on every 10 counts thus 6 designate beef cattle were tagged in the abattoir and the samples of beef were collected from the beef owners (butcher) on the other day. In the second day of sampling a total of 62 cattle were slaughtered and the carcass samples were taken on every 10 counts thus 6 designate beef cattle were tagged in the abattoir and the samples of beef were collected from the beef owners (butcher) on the other day. Each sample weighs a kilogram. The samples were collected by the classical method of excision from all portions of the carcass [15]. The excision method was preferred over wool swab as the numbers of bacteria recovered by excision sampling exceed between $50 \%$ and $90 \%$ of those recovered by cotton wool swabs [16]. The samples were collected aseptically into sterile polyethylene bags and transferred immediately to the laboratory. The samples were collected in two non-consecutive days of sampling. The abattoir personnel were not informed about the sampling of carcass so that they continue as normal [17].

The methods described by the Nordic Committee on Food Analysis (NMKL) were adopted to analyze each of the parameters considered. Ten grams of each beef sample and $90 \mathrm{ml}$ of normal sterile saline water was homogenized in a stomacher bag blender for 1-3 minutes. Appropriate dilutions $(0.1$ and $0.01 \mathrm{ml})$ were made and plated on the following media for microbial count.

\section{Detection of aerobic plates}

One millilitre of each dilution was poured into a sterile Petri dish and about $15 \mathrm{ml}$ of molten plate count agar (PCA) was added. The inoculum was evenly spread by gently shaking and left to solidify for 10-15 minutes. Then the plates were incubated at $30^{\circ} \mathrm{C}$ for 72 hours. Colonies on selected plates were counted using a colony counter [18].

\section{Detection of Staphylococcus spp}

One millilitre of each dilution was pipetted into a Petri dish that contains Baird-parker agar plates. The inoculum was evenly spread by shaking and incubated in incubators for 24 and 48 hours at $37.0 \pm$ $1.0^{\circ} \mathrm{C}$. Typical colonies of Staphylococcus spp (black or grey, shining and convex), diameter 1.0-1.5 mm after 24 hours incubation and 1.5$2.5 \mathrm{~mm}$ after 48 hours incubation and with each colony surrounded by a clear zone were isolated and tested for coagulase positive as a confirmatory test and finally recorded [18].

\section{Detection of total coliform and fecal coliform}

Total coliform and fecal coliform were detected by transferring 1.0 $\mathrm{ml}$ of sample from each dilution into sterile Petri dish and $15 \mathrm{ml}$ of molten and cooled Violet Red Bile agar were added. The inoculum was evenly mixed by shaking and left to solidify and incubated the plates at $37^{\circ} \mathrm{C}$ and $44.5^{\circ} \mathrm{C}$ for $24 \pm 2$ hours. The red colonies were counted and then confirmed by transferring the selected five colonies to BGB and E.C Broth by their gas production [18].

\section{Detection of Escherichia coli}

Suspected colonies of the fecal coliform were confirmed in E.C Broth at $44^{\circ} \mathrm{C}$ for 24 hours with the production of gas, after which one loop of the positive tube were transferred into Tryptone water and incubated at $44^{\circ} \mathrm{C}$ for 48 hours 3 drops of Kovac's reagent was added to the test culture and observed for any reaction. Formation of red colour indicated a positive reaction, thereby confirms the presence of Escherichia coli, and recorded those organisms producing red ring as indole positive [19].

\section{Detection of Salmonella and Shigella spp}

The NMKL method No 71 was used to isolate and enumerate the salmonella and shigella spp. (Figure 1).

\section{Experimental design, model and statistical analysis}

The experimental design of the study was Completely Randomized Design. The General Linear Model procedure of SAS [20] was employed to analyse the variation between days and batch samples. Mean separation was done by Duncan Multiple Range Test. The following model was used: $Y_{i j k}=\mu+\alpha_{i}+e_{i j k}$

Where; $\mathrm{Y}_{\mathrm{ij}}=$ the response variable,

$\mu=$ Overall mean common to all observation,

$\alpha_{i}=$ treatment effect,

$\mathrm{e}_{\mathrm{ijk}, \mathrm{k}}$ Random error

\section{Results and Discussion}

The overall F-test of model for Aerobic plate (AP), Total Coliform, Fecal coliform, E. coli and staphylococci counts variation across days and batches are given in table 1 and were significantly varied between days of sampling and batches of same day sample $(\mathrm{P}<0.05)$. The variation of these microorganisms in days and batches of same day may indicate the existence of non-consistent unhygienic condition attributed to lack of standard operation procedure that help to control processing systems in the abattoir. Variations in microbial load on fresh carcasses between sampling days are also reported by several researchers. This report is in good agreement with the report of Charlebois et al. [21] that indicated significant differences in mean fecal coliform counts between the days and sampling location such as front and hind quarters. Significantly higher variation of AP, fecal coliform and E. coli load between days of

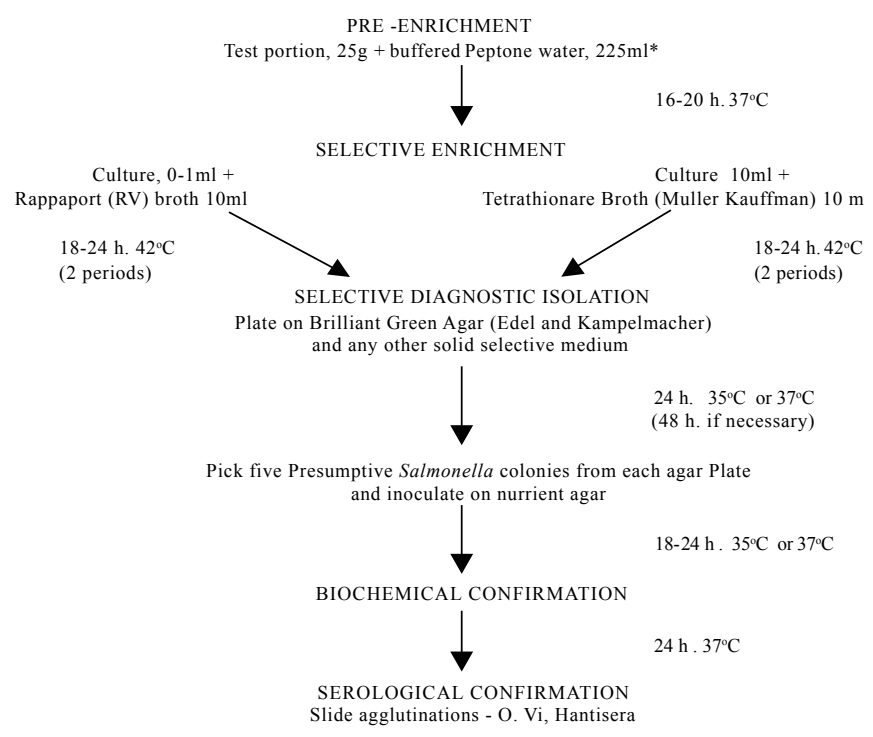

Figure 1: The schematic diagram of salmonella isolation. 
sampling and site of sampling was also reported by de-Moreno et al. $[22]$.

The present report is also in agreement with Koffi-Nevry et al. [23] who reported a statistically significant difference $(\mathrm{P}<0.05)$ in AP, Total coliform, Fecal coliform, E. coli and Staphylococci counts were found between days and samples. The present findings were also comparable with a report of Bosilevac et al. [24] that the prevalence of E. coli O157 and Aerobic bacteria varied in days. Cason et al. [25] also reported a significant difference in $E$. coli counts between the left and right halves. This means that to some extent the degree of microbial load on carcass depend on the care and skill of personnel handling the carcasses.

The Least Square Means of microbial load between sampling days and batches are presented in table 1 . In all considered microbes, day 2 had significantly exceeded day 1 , this imply that microbial load varies from day to day indicating inconsistently unhygienic condition that prevail in the abattoirs. A inconsistently unhygienic condition may be attributed to continuously firing and hiring new unskilled labor forces and lack of training on carcass handling to minimize contamination in addition to lack of stringent quality control system such as GHP and HACCP procedure.

\section{Implication of microbial load}

The mean microbial load counts on beef are given in table 2 . The mean AP, Total coliform, Fecal coliform, E. coli and staphylococci counts were $1.62 \times 10^{5}, 5.29 \times 10^{1}, 9.05 \times 10^{1}, 8.97 \times 10^{1}$ and $5.54 \times 10^{5}$ respectively. All counts exceeded the established standard microbiological contents of beef set by different countries. Salmonella and shigella bacteria were not isolated per $25 \mathrm{~g}$ samples. This report on AP is comparable with Mezgebu and Mogessie [26] that reported an aerobic mesophilic counts that ranged from $2 \times 10^{7}$ to $2 \times 10^{8} \mathrm{cfu} / \mathrm{g}$ in the traditional minced beef locally called 'kitfo'. But AP in current report is higher than that of reported by Badrie et al. and Clarence et al. $[27,28]$ reported AP ranging from $10^{2}-10^{5} \mathrm{cfu} / \mathrm{g}$ and $3.02 \times 10^{3}-5.01 \times 10^{3} \mathrm{cfu} / \mathrm{g}$ in beef investigated in Trinidad and Tobago and Benin City of Nigerian, respectively. This difference may be due to lack of quality control system in the abattoirs. But as high as $8.5 \times 10^{5}-8.7 \times 10^{10} \mathrm{cfu} / \mathrm{g}$ AP on beef was also reported by Mukhopadhyay et al. [29] in India.

Aerobic plate count is a general measure of the microbiological status of meat [8].

According to FAO [30] microbiological standard, the safe level of aerobic plate count is less than $1 \times 10^{4} \mathrm{cfu} / \mathrm{g}$ and the critical condition lies between $1 \times 10^{4}-1 \times 10^{5} \mathrm{cfu} / \mathrm{g}$ and more than $1 \times 10^{5} \mathrm{cfu} / \mathrm{g}$ is not acceptable. According to Anon [8] to confirm beef carcass as safe the AP in all five samples sampled must be less than $5 \times 10^{6} \mathrm{cfu} / \mathrm{g}$ and three samples must be less than $5 \times 10^{5} \mathrm{cfu} / \mathrm{g}$. AP below $\times 10^{5} \mathrm{cfu} / \mathrm{g}$ is acceptable [8]. In the republic of Trinidad and Tobago the acceptable limits of AP is less than $1 \times 10^{5} \mathrm{cfu} / \mathrm{g}$ [27].

The mean Staphylococcus spp count in the studied beef sample is about $5.5 \times 10^{5} \mathrm{cfu} / \mathrm{g}$. This finding is comparable with $3.3 \times 10^{5}-9.12 \times 10^{6}$ cfu/g reported by Mezgebu and Mogessie [26] in Addis Ababa beef serving restaurants. This report is not agreement with the claim of Adams and Moss [31] that the presences of Staphylococcus aureus are usually in small number in normal condition. Staphylococcus spp count is also higher than that of reported by Clarence et al. [28] $3 \times 10^{3}$ $1.8 \times 10^{4} \mathrm{cfu} / \mathrm{g}$ of beef investigated in Benin City metropolis of Nigerian. According to NACMCF [32] Staphylococcus spplevel about $1 \times 10^{5} \mathrm{cfu} / \mathrm{g}$ is regarded as product is clearly unsafe for human consumption. In Trinidad and Tobago republic, the acceptable limit of Staphylococcus spp is less than $1 \times 10^{2} \mathrm{cfu} / \mathrm{g}$ [27].

The mean $E$. coli in beef sample studied was $8.97 \times 10^{1} \mathrm{cfu} / \mathrm{g}$. This is found to be lower when compared with Badrie et al. and Clarence et al. $[27,28]$ that reported $3.1 \times 10^{2}$ and $3 \times 10^{3}-5 \times 10^{3}$ in meats sold in street and kiosks respectively. It is in good agreement with Eisel et al. [33] that reported E. coli of $1 \times 10^{1}-1 \times 10^{2} \mathrm{cfu} / \mathrm{g}$. Biswas et al. [34] claim that $E$. coli are significantly high in beef than in other type of meat. E. coli and Staphylococcus spp are disease causing organisms [17]. The acceptable limit of E. coli in meat is less than $1 \times 10^{2} \mathrm{cfu} / \mathrm{g}$ in Republic of Trinidad and Tobago [27]. According to Anon [8] to confirm beef carcass as safe $E$. coli prevalence in all five samples taken at a time must be less than $5 \times 10^{3} \mathrm{cfu} / \mathrm{g}$ or three samples must be less than $5 \times 10^{2} \mathrm{cfu} / \mathrm{g}$. E. coli and Coliform counts indicate processing hygiene [35]. Sources of meat contamination during slaughter are from animal, processing practices, abattoir facilities and employees $[35,16]$.

The mean total coliform count in fresh carcass sample was $5.3 \times 10^{1}$ $\mathrm{cfu} / \mathrm{g}$. This finding is in agreement with Eisel et al. and Stopforth et al. $[33,36]$ that reported $2.5 \times 10^{1}-1.58 \times 10^{3} \mathrm{cfu} / \mathrm{g}$ and $1.2 \times 10^{1}-6.3 \times 10^{1}$ $\mathrm{cfu} / \mathrm{g}$ for total coliform count in fresh beef samples, respectively. The present finding's figure is much lower than $4.4 \times 10^{3}-4.8 \times 10^{5} \mathrm{cfu} / \mathrm{g}$ reported by Mezgebu and Mogessie [26]. Kornacki [37] claims that coliforms are often best indicator of the hygienic conditions of carcass production processing and handling systems. Therefore, high total coliform obtained in this study might be attributed to poor hygienic condition and product handling practices leading to contamination [38]. The prevalence of fecal coliform count in the fresh beef carcass was $9.05 \times 10^{1} \mathrm{cfu} / \mathrm{g}$. Yalcin et al. [39] reported mean fecal coliform counts of the different sites of the carcasses were $3.16-8.9 \mathrm{cfu} / \mathrm{cm}$. All the counts exceeded the standard microbiological criteria set by NACMCF (National Advisory Committee on Microbiological Criteria for Foods) for beef meat.

\begin{tabular}{|c|c|c|c|c|c|}
\hline Variables & APC(cfu in $\left.\log _{10}\right)$ & TCC(cfu in $\left.\log _{10}\right)$ & FCC (cfu in $\left.\log _{10}\right)$ & $E C C\left(c f u\right.$ in $\left.\log _{10}\right)$ & StC(cfu in $\left.\log _{10}\right)$ \\
\hline Days & * & $* * *$ & Ns & ns & * \\
\hline Day 1 & $4.945^{b}$ & $1.126^{b}$ & 1.653 & 1.649 & $5.481^{\mathrm{b}}$ \\
\hline Day 2 & $5.474^{a}$ & $2.320^{a}$ & 2.260 & 2.256 & $6.006^{a}$ \\
\hline Batches & $* * *$ & $* * *$ & $* * *$ & $* * *$ & $* * *$ \\
\hline Sample 1 & $4.977^{\mathrm{b}}$ & $1.255^{\mathrm{b}}$ & $2.312^{a}$ & $2.299^{a}$ & $4.977^{\mathrm{b}}$ \\
\hline Sample 7 & $4.913^{c}$ & $0.998^{c}$ & $0.994^{b}$ & $0.998^{b}$ & $5.984^{a}$ \\
\hline Sample 8 & $5.984^{a}$ & $2.299^{a}$ & $2.221^{a}$ & $2.221^{a}$ & $5.998^{a}$ \\
\hline Sample 9 & $4.963^{b}$ & $2.341^{a}$ & $2.301^{a}$ & $2.292^{\mathrm{a}}$ & $6.013^{a}$ \\
\hline CV $(\%)$ & 0.288 & 2.239 & 2.927 & 2.097 & 0.492 \\
\hline
\end{tabular}

$\mathrm{Ns}=$ Nonsignifican at $\mathrm{P}>0.05,{ }^{*}=\mathrm{P}<0.05$, cfu = colony forming unit, $\log _{10}=$ to common logarithm, APC = Aerobic plate count, TCC = Total coliform count, FCC = Fecal coliform count, $\mathrm{ECC}=$ Escherchia coli count, $\mathrm{StC}=$ Staphylococci counts. Means with the same letter in the same column are not significantly different at $\mathrm{P}>0.05$.

Table 1: Effect of days and batches on microbial load of carcasses (LS means). 
According to this study Salmonella spp and Shigella spp were not isolated in meat. Biswas et al. [34] claimed that Salmonella spp is the primary microbial challenge for poultry. But Amenu [40] reported $30 \%$ of beef produced in Arba Minch town's abattoir and beef retailing outlets (in Ethiopia) has salmonella strains. This high prevalence rate could be due to the fact that most of the Ethiopian carcass dressers in the rural areas and retailing butchers in rural town have home reared poultry and may have carried the Salmonella strains and transferred it to carcass. But the Adama case could be different because it is mega town with no or less number of home reared poultry in the town. To judge meat as satisfactory or acceptable regarding Salmonella the prevalence should be less than $4 \%$ or less that $2 / 50$ sample [8]. According to Badrie et al. [27] in Trinidad and Tobago republic, the acceptable limit of Salmonella is zero per $25 \mathrm{~g}$ sample. Haimanot et al. [41] report indicates that $60 \%$ of Ethiopian butchers and $100 \%$ of Ethiopian abattoir were found to be positive for pathogenic micro organisms.

\section{Indicator micro-organisms}

Table 3 shows the correlation degrees between the microorganisms. There was no significant correlation between AP and total coliform counts $(\mathrm{P}>0.2)$. This report is not in agreement with Cason et al. [25] that reported a correlation coefficient of 0.69 between AP and total coliform $(\mathrm{P}<0.0001)$ implying further study is needed to prove by increasing sample size and colony counting accuracy. But is in good agreement with Cason et al. [25] report of a correlation coefficients of 0.69 and 0.39 between E. coli and coliform and between AP and E. coli $(\mathrm{P}<0.0001)$ respectively. Significant correlation between E.coli and AP is also reported by Kornacki [37] that E.coli were highly correlated with AP in bovine carcasses. This means, if there is significant correlation between the microbes one of the other could be examined which could indicate the likely existence of the correlated microbe. Examining the indicator microbe will definitely minimize costs and laborious laboratory work. Thus the one used to examine about the other is called indicator. For example, E. coli is used as an indicator organism for the possible presence of pathogens like coliforms and fecal-coliforms. E. coli are particularly useful as indicator of contamination [42].

The routine monitoring for all the possibilities is either impossible or impractical [43]. The solution to the problem has been the use of indicator bacteria that would be present when potential pathogen

\begin{tabular}{|c|c|c|c|c|}
\hline Variables & N & Mean count cfu/g & Log Mean & SD \\
\hline Aerobic Plate count & 12 & $1.62 \times 10^{5}$ & 5.210 & 0.468 \\
\hline Total coliform count & 12 & $5.29 \times 10^{1}$ & 1.723 & 0.631 \\
\hline Fecal coliform count & 12 & $9.05 \times 10^{1}$ & 1.957 & 0.583 \\
\hline E-coli count & 12 & $8.97 \times 10^{1}$ & 1.953 & 0.577 \\
\hline Staphylococcus count & 12 & $5.54 \times 10^{5}$ & 5.744 & 0.463 \\
\hline
\end{tabular}

Salmonella spp and shigella spp are not isolated per $25 \mathrm{~g}$ samples of beef, SD = standard deviation.

Table 2: Mean microbial load of beef in colony forming unit and at common log.

\begin{tabular}{|c|c|c|c|c|c|}
\hline Variables & APC & T coliform & F coliform & E-coli & Staphylococ.spp \\
\hline APC & 1 & 0.57 & 0.32 & 0.32 & 0.29 \\
\hline Total coliform & & 1 & 0.66 & 0.66 & 0.46 \\
\hline Fecal coliform & & & 1 & 0.99 & -0.34 \\
\hline E-coli & & & & 1 & -0.34 \\
\hline Staphylococ.spp & & & & & 1 \\
\hline
\end{tabular}

$\mathrm{ns}=$ non-significant correlation, $\mathrm{APC}=$ aerobic plate count, $E$-coli $=$ Escherichia coli, staphylococ $=$ staphylococci, $\mathrm{F}$ coliform $=$ fecal coliform, $\mathrm{T}$ coliform $=$ Tota coliform

Table 3: Correlation matrix between the common micro-organisms in beef. containing material was present. Fecal coliform bacteria are used as indicators of fecal contamination and of the potential presence of pathogens [44]. In addition, the use of indicators is attractive because it reduces the complexity and cost of analyzing samples for individual pathogens [44]. Total coliform, fecal coliform, and E. coli are all indicators of wholesomeness of products [45]. Coliform bacteria will not always likely cause illness [45]. But the presence of coliform bacteria in product indicates that other disease-causing organisms (pathogens) may be present in the production system. The presence of fecal coliforms is indicative of fecal contamination and of the potential presence of enteric pathogens especially bacterial pathogens [44]. Thus, the above microbial load table 2 indicates the presence of health threatful microbe on the meat produced in Adama town. To avoid such threat meat products should be fried with optimum cooking temperature.

\section{Summary}

This study was conducted to explore the overall microbiological quality of beef in Adama town, Oromia region, Ethiopia. The study entails the specific objectives of investigating microbiological qualities of beef from Arsi cattle. Aerobic Plate, Total Coliform, Fecal coliform, E. coli and Staphylococci counts were significantly varying between days and batches $(\mathrm{P}<0.05)$. The variation of these microorganisms between days and batches of same day may indicate the existence of inconsistent unhygienic carcass harvesting practices and this condition is attributed to lack of the basic Good Hygienic Practices (GHP) procedure in the abattoir. In addition to this, abattoir staffs are not given any training on carcass handling to prevent excessive contamination. The mean AP, total coliform count, fecal coliform count, E. coli count and staphylococci count were $1.62 \times 10^{5}, 5.29 \times 10^{1}, 9.05 \times 10^{1}, 8.97 \times 10^{1}$ and $5.54 \times 10^{5}$ respectively. All counts exceeded the already established standard microbiological contents of beef set by different countries. Salmonella and shigella bacteria were not isolated per $25 \mathrm{~g}$ samples.

The abattoirs have weak supervision and inspection by higher officials. Municipality abattoirs are operating in poor hygienic and traditional system. Generally, the studied abattoirs had poor meat producing and processing facilities. Meats are normally transported to the butchers' shop either in vans, minibus, taxi, three wheel motor cycle and horse-cart. This exposes the meat to a number of pathogens some of which may be pathogenic. The high load of microorganisms could also be the result of unhygienic handling and processing using (in butchers' shop) unclean knives, cutting boards, and storage ladder added to the poor hygienic status of food handlers. The high number of staphylococci, which is usually related to human skin and clothing is indicative of this situation.

\section{Recommendation}

Based on the findings of the study, the following recommendations are forwarded.

Obviously, in Ethiopian big towns' a large number of beef consumers prefer to eat raw beef but since general hygienic conditions of the abattoirs and carcass production, the process of poor beef is not microbiologically wholesome. Consumers in Adama are advised to cook beef appropriately to avoid intoxication due to microbes.

The study of microbial load demonstrated the importance of sanitation of retail beef cuts. The abattoirs have to put due attention on the ways that minimize contamination during carcass harvesting by following modern sanitation procedures and implementing stricter operation laws. The GHP/HACCP procedure can help to prevent or minimize biological contamination. 
Further research work is needed to characterize the microbiological quality of beef being produced from other Ethiopian breed cattle.

\section{Acknowledgments}

I would like to express my deep gratitude to Oromia Agricultural Research Institute for funding this research work. I have special thanks to Mr. Eshetu Gemechu for his unreserved assistance during this study. I have also special thanks to Mr Shalo Bakuye and Mr. Taha Mume for arranging and facilitating vehicle to carry out this thesis work smoothly. I would like to offer my special thanks to all finance staff members of Adami Tulu Agricultural Research Center especially Beyene Kuresso and Gemeda Guye for facilitating and settling financial transactions. would also like to extend my thanks to the technicians of the laboratory of the Nutrition and Microbiology of Ethiopia Health and Nutrition Research Institute for their professional and friendly assistance during running the analysis of bee samples for microbiological parameters. My special thanks are extended to all the staff of Adama municipality abattoir for their kind cooperation and help.

\section{References}

1. Ayele S, Assegid W, Jabbar MA, Ahmed MM, Belachew H (2003) Livestock marketing in Ethiopia: A review of structure, performance and development initiatives. Socio-economics and Policy Research Working Paper 52. ILRI (International Livestock Research Institute), Nairobi, Kenya.

2. Nell AJ (2006) Quick scan of the livestock and meat sector in Ethiopia, Issues and opportunities. Wageningen International, Wageningen, the Netherlands.

3. IFAD (2010) Livestock Position Paper

4. MoFED (2010) Brief Note on the 2003 (EFY) GDP Estimates series

5. von-Seggern DD, Calkins CR (2001) Physical and Chemical Properties of 39 Muscles from the Beef Chuck and Round. Nebraska Beef Cattle Reports.

6. US-CME (2009) CME: Global Consumption, Production and Trade Patterns. The Poultry Site Latest News.

7. Kirton AH (1989) Current Methods of On-Line Carcass Evaluation. J Anim Sci 67: 2155-2163.

8. Anon (2006) Microbiological Criteria

9. The World Bank (2004) Ethiopia: Country economic memorandum. Background report: A Review of Manufacturing Activities with High-Value Exports Growth Potential in Ethiopia.

10. Herenda D, Chambers PG, Ettriqui A, Seneviratna P, da Silva TJP (2000) Manual on meat inspection for developing countries. FAO Animal Production and Health Paper 119, Food and Agriculture Organization of the United Nations Rome, Italy.

11. von-Braun J (2010) The role of livestock production for a growing world population.

12. Anon (2011) Climate, weather, temperatures - Debre-zeit (Bishoftu).

13. Zoover (2011) Weather forecast Lodge Safari Lodge. Accessed on June 25

14. Google Earth (2012) Google Earth version 6.1.2 Geographical map information tracking system. US Department of state geographer.

15. Soyiri IN, Agbogli HK, Dongdem JT (2008) A Pilot Microbial Assessment of Beef Sold in the Ashaiman Market, A Suburb of Accra, Ghana. African Journal of Food, Agriculture, Nutrition and Development 8.

16. Gill CO (1998) Microbiological contamination of meat during slaughter and butchering of cattle, sheep and pigs. In: The Microbiology of Meat and Poultry. ( $1^{\text {st }}$ edn), Blackie Academic and Professional, London, UK.

17. Adzitey F, Teye GA, Kutah WN, Adday S (2011) Microbial quality of beef sold on selected markets in the Tamale Metropolis in the Northern Region of Ghana. Livestock Research for Rural Development 23

18. The Nordic Committee on Food Analysis: General guidelines on Salmonella, Shigella, Staphylococci and E.coli spp bacteria determination in foods. Review paper, Norwegian National Committee, Oslo, Norway.

19. The Nordic Committee on Food Analysis: General guidelines on Aerobic microorganisms and coliform spp bacteria determination in foods. Review paper, Norwegian National Committee, Oslo, Norway.

20. SAS (2008) (Statistical Analysis Software). Users' Guide: Statistics Version 9.1, SAS institute inc, Cary, NC
21. Charlebois $R$, Trudel $R$, Messier $S$ (1991) Surface contamination of beef carcasses by fecal coliforms. J Food Protect 54: 950-956.

22. de-Moreno AL, Huerta-Leidenz N, Ortiz Y, Valera-Matos M, Smith GC (2008) Microbiological Contamination on Beef Carcasses in a Small Abattoir in Venezuela.

23. Koffi-Nevry R, Koussemon M, Coulibaly OS (2011) Bacteriological Quality of Beef Offered for Retail Sale in Cote d'ivoire. American Journal of Food Technology 6: 835-842.

24. Bosilevac JM, Arthur TM, Wheeler TL, Shackelford SD, Rossman M, et al. (2004) Prevalence of Escherichia coli 0157 and levels of aerobic bacteria and Enterobacteriaceae are reduced when hides are washed and treated with cetylpyridinium chloride at a commercial beef processing plant. J Food Prot 67: $646-650$

25. Cason JA, Berrang ME (2002) Variation in Numbers of Bacteria on Paired Chicken Carcass Halves. Poultry Sci 81: 126-133.

26. Mezgebu T, Mogessie A (1998) Microbial load and incidence of Salmonella spp. in 'kitfo', a traditional Ethiopian spiced, minced meat dish. Ethiopian Journal of Health Development 12: 135-140.

27. Badrie N, Joseph A, Chen A (2004) An observational study of food safety practices by street vendors and microbiological quality of street-purchased hamburger beef patties in Trinidad, West Indies. Internet Journal of Food Safety 3: 25-31.

28. Clarence SY, Obinna N, Chinedu SN (2009) Assessment of bacteriologica quality of ready to eat food (Meat pie) in Benin City metropolis, Nigeria. African Journal of Microbiology Research 3: 390-395.

29. Mukhopadhyay HK, Pillai RM, Pal UK, Kumar VJA (2009) Microbial quality of fresh chevon and beef in retail outlets of Pondicherry. Tamilnadu Jouranl of Veterinary and Animal Sciences 5: 33-36.

30. FAO (2007) Meat Processing Hygiene, Meat processing technology for smallto medium-scale producers.

31. Adams MR, Moss MO (2000) Food Microbiology. Royal Society of Chemistry, Cambridge, UK, 479 pp.

32. National Advisory Committee on Microbiological Criteria for Foods (2012) Subcommittees 2010-2012 Subcommittee: Study of Microbiological Criteria as Indicators of Process Control or Insanitary Conditions.

33. Eisel WG, Linton RH, Muriana PM (1997) A survey of microbial levels for incoming raw beef, environmental sources, and ground beef in a red meat processing plant. Food Microbiol 14: 273-282.

34. Biswas S, De A, Patra D, Bhattacharya D (2008) Meat Microbiology vis-àvis Food safety-A Retrospective. FAVA - OIE Joint Symposium on Emerging Diseases, Proceedings, The 15th Congress of FAVA

35. Galland JC (1997) Risks and prevention of contamination of beef carcasses during the slaughter process in the United States of America. Rev Sci Tech 16: $395-404$

36. Stopforth JD, Lopes M, Shultz JE, Miksch RR, Samadpour M (2006) Microbiological status of fresh beef cuts. J Food Prot 69: 1456-1459.

37. Kornacki JL (2011) Testing Indicator Organism Assays: Chaos, Confusion and Criteria.

38. Zelalem Y, Faye B (2006) Handling and Microbial Load of Cow's Milk and Irgo - Fermented Milk Collected from Different Shops and Producers in Central Highlands of Ethiopia. Eth J Anim Prod 6: 67-82.

39. Yalcin S, Nizamlioclu M, Gurbuz U (2001) Fecal coliform Contamination of Beef Carcasses during the Slaughtering Process. J Food Safety 21: 225-231.

40. Amenu Amboma (2012) Prevalence and Antibiotic Resistance of Salmonella Isolated From Beef in Arbaminch, Southern Ethiopia. MSc. Thesis Submitted to Haramaya University, Haramaya, Ethiopia

41. Tassew H, Abdissa A, Beyene G, Gebre-Selassie S (2010) Microbial flora and food borne pathogens on minced meat and their susceptibility to antimicrobial agents. Ethiop J Health Sci 20: 137-143

42. FAO (1994) Traditional Microbiological Quality Control in: Assurance of seafood quality. FAO Corporate Document Repository.

43. Anon ND (2012) Indicators, Coliforms and Fecal streptococci. BioVir laboratories, Benicia. 
Citation: Gebeyehu A, Yousuf M, Sebsibe A (2013) Evaluation of Microbial Load of Beef of Arsi Cattle in Adama Town, Oromia, Ethiopia. J Food Process Technol 4: 234. doi:10.4172/2157-7110.1000234

Page 6 of 6

44. Anon (2003) Fecal coliform as an Indicator Organism: Environmental factsheet WD-WEB-18. New Hampshire, department of environmental services.
45. Anon (2004) Coliform Bacteria and Drinking Water: Environmental Health Fact Sheet. 